\title{
OBRAZ POSTAVENIA BISKUPA V DIELE HISTORIA PERSECUTIONIS AFRICANAE PROVINCIAE TEMPORUM GEISERICI ET HUNERICI REGUM VANDALORUM OD VICTORA Z VITY'
}

\author{
The Portrayal of the Bishop's Position in the Work Historia persecutionis \\ Africanae provinciae temporum Geiserici et Hunerici regum Vandalorum \\ by Victor of Vita
}

\author{
Emanuel Jirkal
}

DOI: 10.17846/CL.2020.13.1.3-15

\begin{abstract}
JIRKAL, Emanuel. The Portrayal of the Bishop's Position in the Work Historia persecutionis Africanae provinciae temporum Geiserici et Hunerici regum Vandalorum by Victor of Vita. Based on the work analysis by Victor of Vita Historia persecutionis Africanae provinciae sub Geiserico et Hunirico regibus Vandalorum, the contribution is dedicated to the portrayal and representation of the bishop in Africa on the territory of Vandal kingdom. It is a specific topic which is up to certain extent closely related to the persecution or rather to the oppression of the Catholic Church from the side of ruling Vandals who often tried to violently convert the majority of Roman population belonging to the Catholic Church to the Arian faith. Through the portrayal and representation of the bishop, the contribution follows more levels such as addressing the bishops, bishop's level of knowledge, their preparedness to undergo suffering and even death because of their faith, charity activities, humility and modesty, the preparedness to serve to needy, oppressed and poor people. In the second part, the contribution dedicates to the comparison of the position and bishop's activity in Africa and in the rest of the Roman Empire. Under Vandal rules, bishops in Africa had, of course, the limited possibilities to carry out their function and to secure its important components. Their preparedness to tackle serious theological issues which separated Vandal Arians and the Catholic Church underwent a great proof.
\end{abstract}

Keywords: church history, early Christianity, persecution of the Christians, Vandal kingdom, Victor of Vita, bishop

\begin{abstract}
Abstrakt: JIRKAL, Emanuel. Obraz postavenia biskupa v diele Historia persecutionis Africanae provinciae temporum Geiserici et Hunerici regum Vandalorum od Victora $z$ Vity. Príspevok je venovaný postaveniu a prezentácii biskupa v Afrike na území Vandalského královstva na základe analýzy diela Victora z Vity Historia persecutionis Africanae provinciae sub Geiserico et Hunirico regibus Vandalorum. Je to špecifická téma, ktorá do istej miery úzko súvisí s prenasledovaním alebo skôr s útlakom katolíckej cirkvi zo strany vládnucich Vandalov, ktorí sa snažili často aj násilím obrátit väčšinové rímske obyvatelstvo patriace do katolíckej cirkvi na ariánsku formu vierovyznania. Na postavení a prezentácii biskupa si príspevok všíma viacero rovín, ako je oslovovanie biskupov, vzdelanie biskupov, ich pripravenoste podstúpit utrpenie a dokonca smrt' za svoju vieru, charitatívnu činnost', pokoru a skromnost',
\end{abstract}

1 Štúdia je napísaná v rámci riešenia projektu VEGA č. 1/0006/18 Imago episcopi - moc biskupa a jeho prezentácia v stredoveku. 
pripravenost slúžit potrebným, utláčaným a núdznym. V druhej časti sa príspevok venuje porovnaniu postavenia a činnosti biskupa v Afrike a vo zvyšku Rímskeho impéria. Samozrejme, že pod Vandalskou vládou mali biskupi v Afrike obmedzené možnosti vykonávat svoju funkciu a zabezpečovat jej dôležité súčasti. Velkú skúšku podstúpila ich pripravenost̉ viest’ závažné teologické otázky, ktoré rozdelovali vandalských ariánov a katolícku cirkev.

Klúčové slová: dejiny cirkvi, rané krestanstvo, prenasledovanie krestanov, Vandalské královstvo, Victor $z$ Vity, biskup

Pre dejiny Vandalského královstva, ktoré sa vytvorilo v neskorej antike na území rímskej Afriky a trvalo od r. 429 do r. 534 po Kr., máme k dispozícii najmä písomné pramene. Medzi najdôležitejšie patria História prenasledovania v Afrike v dobe vandalských panovníkov Geisericha a Hunericha od Victora z Vity z konca 5. st. (Victor Vitensis 1879; Victoris episcopi Vitensis 1881; Victor von Vita 2011) a Vojna s Vandalmi z pera neskororímskeho autora Prokopia z polovice storočia šiesteho. Prokopios na začiatku svojho rozprávania podáva zhrnutie udalostí odohrávajúcich sa v Afrike pred vojenským zásahom Rímskej ríše za vlády cisára Iustiniana I. (Justiniána) do diania vo Vandalskom královstve (Prokopios von Kaisareia 1966-1971).

Hlavnou témou diela Victora z Vity, ako prezrádza už jeho názov, je tlak Vandalov, ktorí vyznávali krestanstvo v jeho ariánskej forme, voči katolíkom, ${ }^{2}$ ktorý prerástol až do vel’mi krutého zaobchádzania, z pohladu katolíkov až do prenasledovania s vieroučnými oponentmi. Hlavný nápor voči vierovyznaniu väčšinového afrorománskeho obyvatel’stva sa odohrával za vlády dvoch prvých vandalských panovníkov Geisericha (428 - 477 po Kr.), ktorý bol vlastným zakladatelom a tvorcom Vandalského královstva a jeho syna Hunericha (477 - 484 po Kr.) $)^{3}$

Pri práci s prameňmi bola použitá priama metóda, vd’aka ktorej sa bádatel dostáva priamo $\mathrm{k}$ informáciám, ktoré mu podáva prameň. Je to hlavná metóda použitá v tejto štúdii. Pritom $\mathrm{v}$ rámci skúmania diela Victora $\mathrm{z}$ Vity bola použitá tiež metóda sondy, kedže sa zameriavam na určité aspekty obsiahnuté v tomto diele. Pri viacerých záležitostiach sa používa tiež komparatívna metóda, ktorá sa zameriava na porovnávanie situácií v rôznych častiach Rímskeho impéria, ktoré sú následne porovnávané s možnost̉ami biskupov v Afrike.

Victor z Vity je súčasníkom väčšej časti popisovaných udalostí a mnohé z nich pozná ako očitý svedok, čo mimoriadnym spôsobom zvyšuje cenu jeho diela ako historického prameňa. To, čo o autorovi vieme, sa dá bohužial' získat len z jeho vlastného diela, podobne ako pri mnohých iných antických autoroch. V rukopisoch je autor diela uvádzaný ako episcopus patriae Vitensis - biskup z Vity, jeho rodného mesta, ktoré je dnes neznáme (Vössing 2011, 12). Meno mesta sa vyskytuje ešte v jednom súdobom prameni v Notitia provinciarum et civitatum Africae (1881, 115-134), čo je vlastne súpis všetkých afrických biskupov a miest, v ktorých boli biskupstvá, zaznamenaných zrejme pre potrebu vandalského krála v súvislosti s vieroučnou ariánsko-katolíckou debatou, na ktorú sa mali dostavit’ všetci katolícki biskupi (Steinacher 2016, 330). V tomto zozname nachádzame údaj, že Victor biskup z mesta Vita na debatu nedorazil (Notitia provinciarum et civitatum Africae 1881, Nomina episcoporum provinciae Byzacenae 44; Notitia provinciarum et civitatum Africae 1881, 125). Tu treba hned' povedat', že tento Victor z Vity je len menovec autora Historiae

2 Výrazy katolík, katolícky používam podla úzu využívaného v historickej spisbe, ktorá sa venuje svetským alebo cirkevným dejinám staroveku, tieto výrazy sa využívajú najmä na rozlíšenie rozdielu medzi krestanskou cirkvou a heretickými smermi, kde katolícky znamená pravoverný (Steinacker 1989, 73-74; Suchánek - Drška 2013, 94-102; Pietri 2001, 653; Steinacher 2016, 246; Moorhead 1992, X).

3 K dejinám Vandalov v Afrike vyšlo viacero monografií, v poslednej dobe vyšli Steinacher (2016); Vössing (2014); Merills (2004). 
persecutionis, pretože ten sa tejto debaty určite zúčastnil (Vössing 2011. 12-13). Victor mal velmi blízky vztah s kartáginským biskupom Eugeniom $(480 / 1-496)^{4}$, nachádzame ho totiž v jeho blízkosti počas teologickej a vieroučnej debaty nariadenej vandalským králom Hunerichom v r. 484 po Kr., ktorá mala rozhodnút o tom, ktorá viera je pravdivá, či ariánska vyznávaná Vandalmi alebo katolícka, ku ktorej sa hlásilo väčšinové afrorománske obyvatel’stvo. Debata viedla napokon k rozhodnutiu krála poslat takmer všetko katolícke duchovenstvo do vyhnanstva, do ktorého sprevádzali biskupa Eugenia tiež ludia z jeho okolia a medzi nimi aj Victor (Victor Vitensis 3.34; 3.43; Victor von Vita 2011, 124;130; Steinacher 2016, 251-253; Vössing 2011, 13). Ako sa však zdá, jeho tento trest nepostihol a sprevádzal svojho biskupa dobrovolne. Ked' Eugenius dostal povolenie vrátit’ sa spät do Kartága, Victor sa vrátil s ním. V Kartágu sa potom mohol pustit do spísania záverečnej podoby svojho diela, pričom mohol určite využívat' cirkevné archívy hlavného mesta (Moorhead 1992, xv; Vössing 2011, 13).

Táto štúdia sa venuje prezentácii biskupa, ktorá, kedže vychádza z historicko-apologetického diela, je u Victora z Vity redukovaná zväčša na oslovenie biskupa, jeho prívlastky a v niektorých prípadoch tiež na opisy biskupových činov v prospech svojho cirkevného spoločenstva. Napriek tomu sa tu dajú nájst' aj dalšie informácie $\mathrm{k}$ postaveniu biskupa $\mathrm{v}$ spoločnosti a $\mathrm{k}$ jeho činnosti. ${ }^{5} \mathrm{~K}$ osobe biskupa a $\mathrm{k}$ jeho postaveniu v rámci antickej spoločnosti patrí vela činností, ktoré musel biskup v rámci svojho spoločenstva vykonávat. Druhou vrstvou štúdie teda bude snaha poukázat’ na skutočnosti, ktoré sa $\mathrm{v}$ rámci činnosti biskupa dajú vysledovat tiež $\mathrm{v}$ Afrike prostredníctvom spisu Victora $\mathrm{z}$ Vity. Pri biskupoch sa dá sledovat' v neskorej antike viacero faktorov, ktoré výrazne ovplyvňovali výkon ich funkcie. Prvým krokom bolo ustanovenie biskupa do jeho funkcie, pri ktorej hrali významnú úlohu tiež všetci členovia krestanského spoločenstva, spolu s honoráciou mesta a okolitými biskupmi. Katolícka cirkev zastáva názor, že základom cirkevných spoločenstiev bola biskupská správa a že biskupi boli uvádzaní do svojho úradu od počiatku na základe apoštolskej postupnosti, čo znamená, že biskupi sú nástupcami apoštolov a preberajú ich právomoci pri riadení spoločenstiev. ${ }^{6}$ Tendencia takto vysvetlovat počiatky biskupskej správy sa opiera o viaceré antické pramene pochádzajúce z 2. a d’alších storočí. Medzi dôležité svedectvá patria spisy Klimenta Rímskeho a jeho list Korintanom (1 Clem 42.4-5; Der erste Clemensbrief 1889, 129-130; 1 Clem 44,1-2; Der erste Clemensbrief 1889, 131), čo je najstaršie svedectvo tejto tradície; Irenej z Lyonu (Eirenaios Lugdunensis) a jeho spis Proti herézam (Iren. adv. haer. 3.3.1-2; Sancti Irenaei 1957, 848; Iren. adv. haer. 4.26.2; Sancti Irenaei 1857, 1053-4; Iren. adv. haer. 4.33.8; Sancti Irenaei 1857, 177-8); Tertullianus a jeho spis Predpis proti herézam (Tert. praescr. 20.5; 21.4; 32.1-3); alebo Cyprianus v liste 69 (Cypr. epist 69.3; Cyprianus 1881, 752). Svedectvo prameňov však nie je úplne jednoznačné, pretože mnohé hovoria o volbe biskupa v cirkevných obciach. Volba vhodného kandidáta bola však len jedným z potrebných krokov, ktoré viedli k obsadeniu biskupského stolca v danom meste. Ďalším dôležitým krokom bol súhlas biskupov okolitých miest alebo celej provincie. A napokon museli biskupi prítomní na ordinácii vložit na adepta svoje ruky a týmto spôsobom mu odovzdat dary Ducha svätého a až potom sa nový biskup mohol ujat svojich

4 Eugenius neskonal vo svojom úrade, ale vo vyhnanstve v Galii v r. 505 (Steinacher 2016, 283).

5 Podobnou témou sa zaoberá monografia Vandalen, Barbaren und Arianer bei Victor von Vita (Howe (2007). Kedže mu ide o prehodnotenie obrazu Vandalov ako sebavedomých ariánov, katolíckym biskupom sa venuje len, ak ich porovnáva s ariánmi.

$6 \$ 861$ - Biskupi nástupcovia apoštolov: „Aby im zverené poslanie pokračovalo aj po ich smrti, zanechali svojim bezprostredným spolupracovníkom akoby závetom úlohu pokračovat’ v diele, ktoré oni započali a upevňovat ho, porúčajúc im bedlit nad celým stádom, nad ktorým ich Duch Svätý ustanovil za dozorcov, aby pásli Cirkev Božiu. Ustanovili teda týchto mužov a potom im uložili, aby po ich smrti preberali ich službu iní osvedčení mužovia“ (Katechizmus katolíckej cirkvi 1998, 88). 
povinností (Neumann 1980, 665; Markschies 2005, 194-195).7 Dôležitým predpokladom pre dobrý výkon biskupskej funkcie bol sociálny pôvod biskupa a jeho vzdelanie, ktoré záviselo práve od jeho pôvodu a možností jeho rodiny mu vzdelanie poskytnút. Vzdelanie bolo dôležité tiež, pretože cirkevný majetok postupne narastal na velkosti, či už hnutel'nom alebo nehnutel’nom. Biskup tak musel byt dostatočne vzdelaný, aby dokázal tento majetok správne spravovat. Dôležitými príjmami boli dary členov spoločenstva a postupne ich v objeme prerástli cisárske donácie, dary bohatých členov spoločenstva a rôzne odkazy, najmä testamentárne v prospech cirkvi. Mnohé biskupstvá boli mimoriadne bohaté, ako Rím, Antiochia alebo Alexandria, ktoré mohli podporovat tisíce núdznych a budovat vel'kolepé stavby. Financie boli využívané pri správe cirkevného majetku a hlavným účelom cirkevných príjmov bola starostlivost̉ o chudákov, teda charitatívna činnost'. Jej dôležitým aspektom bola starostlivost’ o tých, ktorí to najviac potrebovali, o chorých, pútnikov, vdovy, siroty. Pre nich všetkých cirkev prostredníctvom svojich biskupov, ktorí na to často venovali celý svoj vlastný majetok, stavala špecializované stavby - chudobince, nemocnice, domovy pre vdovy a pod. Biskupi týmto spôsobom menili vzhlad a charakter antických miest, kde centrom už nebolo rímske fórum, ale kostol s biskupským sídlom a budovami spomenutých sociálnych inštitúcií. Biskupi v rámci Rímskeho impéria zároveň požívali rozličné privilégiá, ktoré robili z biskupskej funkcie velmi lukratívny post. Medzi privilégiá patrili oslobodenia od rôznych nútených prác, služobných povinností a dokonca aj od platenia daní. Dôležitým privilégiom bola skutočnost', že biskupi boli vyňatí zo svetského súdnictva a v prípade nutnosti boli súdení súdom svojich kolegov biskupov. V prípade súdnictva sa od Constantina I. (Konštantína I.) mohli ludia obrátit nie na štátny, ale na biskupský súd, ktorého rozhodnutie bolo konečné (Cod. Theod. 1.27.1; Codex Theodosianus 1962, I.2, 47). Významnou právomocou bola možnost̉ prepustit na slobodu otrokov pred nastúpeným cirkevným spoločenstvom v prítomnosti biskupa. V rôznych častiach ríše mali biskupi vel’mi dôležité postavenie, napr. v Galii začali riadit aj svetské záležitosti svojich miest, žiadali o zníženie daní alebo vyjednávali mier s barbarskými králmi (Pietri 1995, 634-662; Krause 2018, 329-346; Jirkal 2020 - autocitácia). ${ }^{8}$ Ďalšou dôležitou stránkou biskupskej funkcie boli teologické otázky, ktorým sa venovali rozličné celocirkevné koncily riešiace z hladiska krestanskej viery a vierovyznania mimoriadne závažné otázky, ako boli Božia podstata, či majú Otec a Syn rovnakú alebo odlišnú podstatu, v akom vztahu sú medzi sebou Božia a ludská prirodzenost’ druhej Božej osoby Ježiša Krista alebo postavenie Ducha svätého v rámci Božej trojice. Táto stránka bola velmi dôležitá tiež vo Vandalskom královstve, kde vládnuci Vandali boli ariáni a väčšinové rímske obyvatel'stvo bolo katolícke (Babic 2009, 144-147; Suchánek - Drška 2013, 159-181; Lohse 2003, 31-107).

Najskôr sa pozrieme na postavenie biskupovej osoby v diele Victora z Vity. Hned' prvé, čo padne čitatelovi do očí, sú prívlastky, ktoré Viktor z Vity dáva katolíckym biskupom. Pre neho sú praeclari pontifices et nobiles sacerdotes - preslávni pastieri a vznešení biskupi; quanti sacerdotes - akí významní biskupi (Victor Vitensis 1.5; Victor von Vita 2011, 36); venerabilis

Volbu biskupa $\mathrm{v}$ jeho spoločenstve potvrdzuje viacero antických krestanských prameňov: Traditio apostolica 2 (Traditio apostolica 1991, 214-216); Cyprianus. Epistulae 55.8 (Cyprianus 1881, 629-630); Paulinus. Vita Ambrosii 6 (Paulinus 1961, 16-19); Sulpicius Severus. Vita Martini 9 (Sulpicius Severus 1967, 270-272). Určitý druh volby alebo výberu celým spoločenstvom podla mňa potvrdzuje aj Clemens Rímsky vo svojom liste Korintanom, kde v 44. kapitole hovorí o ustanovení episkopov za súhlasu celej krestanskej obce 1 Clem. 44.3 (Der erste Clemensbrief 1899, 130) podobne je to so štvrtým kánonom Nicejského vyznania viery, kde sa hovorí o potrebnosti súhlasu všetkých biskupov danej provincie (Can. 4). Slovenský preklad tohto kánonu použil tiež slovo volba (Dokumenty prvých dvoch ekumenických snemov 1999, 8).

$8 \mathrm{~V}$ tomto odstavci ide len o zhrnutie rôznych aspektov biskupskej funkcie, jej právomocí a úloh, ktoré museli biskupi vo svojom úrade zvládat. Podrobne v spomenutej sekundárnej literatúre (Pietri 1995, 634-662; Krause 2018, 329-346; Jirkal 2020). 
antistes - ctihodný predstavený (biskup) (Victor Vitensis 1.10; Victor von Vita 2011, 38); episcopos nobiles - vznešení biskupi; episcopi, ... clari atque honorati viri - biskupi, ... slávni a vážení muži (Victor Vitensis 1.14; Victor von Vita 2011, 40); episcopus (Carthaginis) deo et hominibus manifestum - biskup (Kartága) osvedčený pred Bohom aj lud’mi (Victor Vitensis 1.15; Victor von Vita 2011, 40); magni sacerdotes - velkí biskupi (Victor Vitensis 1.17; Victor von Vita 2011, 42); piorum (episcoporum) nomen - meno zbožní (biskupi) (Victor Vitensis 1.22; Victor von Vita 2011, 44); beatus Faustus, Burunitatus episcopus - blažený Faustus, biskup z Buruni (Victor Vitensis 1.38; Victor von Vita 2011,54); sanctus Valerianus Abensae civitatis episcopus - svätý Valerianus, biskup mesta Abensa (Victor Vitensis 1.40; Victor von Vita 2011, 56); episcopus Eugenius, vir sanctus deoque acceptus - biskup Eugenius, svätý muž a Bohu milý (Victor Vitensis 2.6; Victor von Vita 2011, 66; sanctus Eugenius - 2.18, 2.40, 2.43, 2.49, 3.43; Victor von Vita 2011, 74, 88, 92, 130; beatus Egenius - 2.43, 2.54; Victor von Vita 2011, 90, 96); venerabilis Paulus episcopus - ctihodný biskup Paulus (Victor Vitensis 2.21; Victor von Vita 2011, 76); Quintianus honorabilis episcopus - Quintianus ctený biskup (Victor Vitensis 2.22; Victor von Vita 2011, 76); beatus Felix Abbiritanus episcopus - blažený Felix, biskup mesta Abbir (Victor Vitensis 2.26; Victor von Vita 2011, 78); beatus pontifex Cyprianus, Unizibirensis episcopus - blažený pastier Cyprianus, biskup z Unizibiri (Victor Vitensis 2.33; Victor von Vita 2011, 82); periti atque doctissimi viri (episcopi) - skúsení a velmi vzdelaní muži (biskupi); unum ex ipso choro doctorum, nomine Laetum, strenuum atque doctissimum virum - jedného $\mathrm{z}$ tohto zboru učených mužov, menom Laeta, horlivého a velmi vzdelaného človeka (Victor Vitensis 2.52; Victor von Vita 2011, 94-96); beati viri, Hortulanus et Florentianus episcopi - blažení muži, biskupi Hortulanus a Florentianus (Victor Vitensis 3.18; Victor von Vita 2011, 110); sanctus Germanus episcopus - svätý biskup Germanus (Victor Vitensis 3.24; Victor von Vita 2011, 116).

Inou kapitolou pri prezentácii biskupov je ich oslava popisom utrpenia, ktoré podstúpili a vytrpeli pre svoju vieru a pre členov svojich cirkevných spoločenstiev. Vandali boli na rozdiel od väčšinového katolíckeho obyvatel’stva v afrických oblastiach Rímskeho impéria ariáni a považovali sa za Bohom poverených svoju vieru šírit aj násilným spôsobom. Preto vo svojej africkej ríši tvrdo preferovali ariánstvo a utláčali až prenasledovali katolícku cirkev. ${ }^{9}$ Tieto smutné, ba až hrozné príbehy začínajú hned' po príchode Vandalov na africkú pevninu: praeclari pontifices et nobiles sacerdotes ... extincti sunt - preslávni pastieri a vznešení biskupi ... boli pozabíjaní; quanti et quam numerosi tunc ab eis cruciati sunt sacerdotes - akí významní a akí početní biskupi boli vtedy nimi umučení (Victor Vitensis 1.5; Victor von Vita 2011, 36) ${ }^{10}$; episcopos atque laicos nobiles de suis ecclesiis vel sedibus nudos petinus aufugarent - vznešených biskupov a laikov vyhnali z ich kostolov alebo sídiel úplne nahých; multos enim episcopos et laicos, claros atque honoratos viros servos esse novimus Vandalorum - dozvedeli sme sa, že mnohí biskupi a laici, slávni a vážení muži sa stali otrokmi Vandalov (Victor Vitensis 1.14; Victor von Vita 2011, 40); Tunc ... episcopum (Carthaginis), ... nomine Quotvultdeus, et maximam turbam clericorum navibus fractis impositam nudos atque expoliatos expelli praecepit - vtedy však prikázal biskupa (Kartága), ... menom Quotvultdeus, a velký zástup klerikov, nahých a o všetko olúpených, naložit na poškodené lode a vyhnat' (Victor Vitensis 1.15; Victor von Vita 2011, 40). Geiserich ich takto vystavil skúške Božieho súdu, ktorá mala rozhodnút o tom, či je pravé náboženstvo katolícke lebo ariánske. Na vel'ké prekvapenie všetkých sa vel’mi poškodené lode preplavili až do Neapola

\footnotetext{
9 Priebeh spolužitia a konfrontácií Vandalov - ariánov a Afrorománov - katolíkov pozri Bednaříková (2003, 136-162); Steinacher (2016); Vössing (2014); Merrils (2004); priamo zameraný na prenasledovanie je Pietri (2001, 264-299).

10 Pomenovanie sacerdotes prekladá ako biskupi Moorhaed (1992) aj Vössing (2011).
} 
a biskup Quotvultdeus $(431-439)^{11}$ a klerici sa zachránili. To však Geisericha neprimälo uznat' nadradenost' katolíkov a vzdat' sa svojho ariánstva (Bednaříková 2003, 143). Tlak sa stupňoval aj v dobe, ked’ si už Geiserich upevnil svoju pozíciu v Kartágu: Nam et diversiae calumniae non deerant cotidie etiam illis sacerdotibus qui in his regionibus versabantur, quae regis palatio tributa pendebant. Et si forsitan quispiam, ut moris est, dum dei populum admoneret, Pharaonem, Nabuchodonosor, Holofernem aut aliquem similem nominasset, obiciebatur illi, quod in persona regis ista dixisset, et statim exilio trudebatur. Hoc enim persecutionis genus agebatur, hic aperte, alibi occulte, ut piorum nomen talibus insidiis interiret. - Lebo nechýbali rozličné krivé žaloby tiež voči tým biskupom, ktorí zostávali v oblastiach, ktoré platili dane pre královský palác. A ak niekto náhodou, ako bolo zvykom, ked’ napomínal Boží lud, spomenul faraóna, Nabuchodonozora, Holoferna alebo niekoho podobného, vytýkali mu, že to povedal proti osobe krála, a hned' bol poslaný do vyhnanstva. Tento druh prenasledovania sa teda vykonával, tu otvorene, tam tajne, aby meno bohabojní zaniklo pod takýmito úkladmi (Victor Vitensis 1.22; Victor von Vita 2011, 44). Qua de re plurimos sacerdotum tunc novimus relegatos - vieme, že z tejto príčiny bolo vtedy poslaných do vyhnanstva vel'ké množstvo biskupov (Victor Vitensis 1.23; Victor von Vita 2011, 46). Quo livore Arriani succensi dolis eum (episcopum Carthaginis Deogratiam) quam plurimis voluerunt sepius enecare - Ariáni touto závistou rozpálení ho (kartáginského biskupa Deogratia) často chceli usmrtit mnohorakými úskokmi (Victor Vitensis 1.27; Victor von Vita 2011, 48). Tunc enim sanctus Valerianus Abensae civitatis episcopus, dum viriliter sacramenta divina ne traderet dimicasset, foris civitate singularis iussus est pelli, et ita praeceptum est, ut nullus eum neque in domo neque in agro dimitteret habitare. Qui in strata publica multo tempore nudo iacuit sub aere. Annorum erat plus octoginta... - vtedy totiž bolo prikázané, aby svätý Valerianus biskup mesta Abensa, kedže statočne zápasil, aby nemusel vydat posvätné liturgické predmety, bol odohnaný od jednotlivých dverí mesta, a boli také príkazy, aby ho nikto nenechal ani v dome ani na poli. On dlhý čas ležal nahý na verejnej dlažbe pod holým nebom. Mal viac ako osemdesiat rokov... (Victor Vitensis 1.40; Victor von Vita 2011, 56).

Útlak sa ešte vystupňoval za Geiserichovho syna a nástupcu Hunericha: ... quando episcopos, presbyteros, diaconos et alia ecclesiae membra, id est quattuor millia nongentos sexaginta sex, ad exilium heremi destinavit - kol'ko biskupov, presbyterov, diakonov a iných údov cirkvi, celkom štyritisíc devätsto šest'desiatšest', odsúdil do vyhnanstva na púšt. Bol medzi nimi tiež blahoslavený biskup Felix, hoci nevládny a takmer mŕtvy musel íst’ do vyhnanstva a niesli ho naloženého krížom cez somára ako kus dreva (Victor Vitensis 2.26-27; Victor von Vita 2011, 78-80). Ked' král' Hunerich zvolal teologickú debatu o pravosti viery medzi ariánmi a katolíkmi, prenasledoval vzdelaných biskupov rôznymi druhmi trestov, aby sa dišputy nemohli zúčastnit: Iam ad exilium Vibianensem Secundianum impositis centum quinquaginta fustibus miserat episcopum, nec non et Sufetulensem Praesidium, virum satis acutum. Tunc et venerabiles Mansuetum, Germanum, Fusculum et multos alios fustigavit - poslal do vyhnanstva Secundiana biskupa z Vibiany, ked' mu predtým bolo naložených 150 úderov palicou, ako aj Praesidia sufetského, muža dost̉ bystrého. Vtedy aj ctihodných Mansueta, Germana, Fuscula a mnohých iných dal bit palicami (Victor Vitensis 2.45; Victor von Vita 2011, 90-92). Na plánovanú dišputu sa schádzali z celej Afriky a $\mathrm{z}$ ostrovov patriacich Vandalom biskupi do Kartága: Fit silentium diebus multis, quosque peritos quosque et doctissimos viros exinde separaret calumniis adpositis enecandos - nastalo mnoho dní bez rozhovorov, aby všetkých skúsených a všetkých vel'mi vzdelaných mužov (král) spomedzi nich oddelil a následne ich zabil, potom ako boli falošne obžalovaní. Nam unum ex ipso choro doctorum, nomine Laetum, strenuum atque doctissimum virum, post diuturnos carceris squalores incendio concremavit... - lebo jedného $\mathrm{z}$ tohto zboru učených mužov, menom Laeta, horlivého

11 Tiež Quotvultdeus zomrel vo vyhnanstve a to v Kampánii pred 24. októbrom r. 454 (Steinacher 2016, 114). 
a velmi vzdelaného človeka, nechal (král) po dlhotrvajúcich drsnostiach väzenia upálit... (Victor Vitensis 2.52; Victor von Vita 2011, 94-96). Hunerich nechal poslat' biskupa Eugenia k nelútostnému ariánskemu biskupovi Antoniovi, o ktorom bolo známe, že vel'mi kruto zaobchádza s katolíkmi: Antonius... ita eum artiori custodia cinxit, ut nullum ad eum introire permitteret, insuper variis insidiarum atque poenarum suppliciis extinquere cogitaret - Antonius... nasadil na neho takú prísnu väzbu, že nikomu nebolo dovolené k nemu vchádzat', okrem toho ho zamýšlal zahubit’ rôznymi mukami úkladov a trestov (Victor Vitensis 3.43; Victor von Vita 2011, 130). Antoniovi sa do rúk dostal aj iný katolícky biskup Habetdeum a aj ten bol vystavený mnohým utrpeniam, napriek tomu vytrval vo svojej viere: Antonius... cum diversis eum persecutionibus adfligeret nec posset facere Arrianum videretque Christi militem semper in confesione constantem - Antonius... hoci ho vystavil rôznym druhom prenasledovania, Arriana z neho spravit nemohol a videl v ňom Kristovho bojovníka vždy pevne zotrvávajúceho vo svojej viere (Victor Vitensis 3.45; Victor von Vita 2011, 130-132).

Victor vyzdvihuje zároveň obetavost’ a službu biskupov pre členov svojich krestanských katolíckych obcí a zároveň ich charitatívnu činnost', pričom ospevuje ich pokoru, oddanost̉ a zbožnost'. V dobe, práve ked' Vandali dobyli v r. 455 po Kr. Rím, ${ }^{12}$ sedel na kartáginskom biskupskom stolci, predtým dlhú dobu prázdnom, biskup Deogratias (454 - 456/7). Victor najskôr hovorí, že by nikto nedokázal spísat’ všetky skutky, ktoré tento biskup vykonal pre svoje stádo - cuius si nitatur quispiam quae per illum dominus fecerit paulatim excurrere, ante incipient verba deficere, quam ille aliquid valeat eplicare a potom pridáva pripomienku jeho obetavosti a starostlivosti o chorých a bezvládnych, medzi ktorých patrili tiež zajatci z Ríma, ktorých Vandali so sebou privliekli do Afriky a Kartága. Biskup sa o nich staral vo dne v noci a to sa napokon podpísalo na jeho zdraví a po troch rokoch svojej služby zomrel. A bol oplákavaný tak zajatcami, ktorí sa obávali o svoj další osud, ako aj afrorománskymi katolíkmi (Victor Vitensis 1.24-27; Victor von Vita 2011, 4648). Ďalším významným biskupom vždy ochotným slúžit členom svojho spoločenstva bol biskup Cyprianus z Unizibiri: Aderat enim ibi beatus pontifex Cyprianus, Unizibirensis episcopus, consolator egregius, singulos pio et paterno fovebat affectu non sine fluminibus currentium lacrimarum, paratus pro fratribus animam ponere et se ultroneum, si dimitteretur, talibus passionibus dare, qui totum quod habuit egentibus fratribus in illa tunc nessesitate expendit; quaerebat enim occassionem, qualiter confessoribus sociaretur, ipse animi et virtute confessor - bol tam totiž vtedy blažený pastier Cyprianus, biskup z Unizibiri, vynikajúci tešitel', ktorý sa ujímal každého s láskyplnou a otcovskou náklonnostou nie bez prúdov tečúcich sĺz, pripravený pre bratov položit život a dobrovolne sa vydat takým utrpeniam, keby mu to bolo dovolené; on vtedy, všetko čo mal, rozdal núdznym bratom v onej núdzi. Hladal totiž príležitost', ako by sa pripojil k confessorom - vyznávačom, sám duchom a ušlachtilostou vyznávač (Victor Vitensis 2.33; Victor von Vita 2011, 82). ${ }^{13}$

K charitatívnej činnosti patrí aj rozdávanie almužien a vynakladanie darov na potreby cirkvi a núdznych: Elemosynas quoque tales per eum (episcopum Eugenium) dominus dignatus est facere, ut incredibile vidaetur tanta eum impendere, ubi ecclesia totum barbaris tenentibus, ne unius nummi habere cognoscitur facultatem - Pán uznal za vhodné jeho (biskupa Eugenia) prostredníctvom udelovat tol'ké almužny, že sa zdalo neuveritel'né, že môže vynakladat tol'ké prostriedky, ked'bolo známe, že cirkev, kedže barbari ovládali všetko, nemá možnost' vlastnit ani malý peniaz (Victor Vitensis 2.7; Victor von Vita 2011, 66-68).

12 Podrobnosti k dobytiu a vyplieneniu Ríma Vandalmi pozri Steinacher (2016, 196-205); Vössing (2014, 55-60); Babic (2009, 213-214).

13 Confessor - vyznavač bol krestan, ktorý pod hrozbou trestov a často pod hrozbou smrti verejne vyznal svoju vieru. Cyprianus nepatril k vyhnancom, ale sprevádzal ich dobrovolne (Victor von Vita 2011, 173 pozn. 168). 
K obetavosti patrila tiež skromnost' života, pokora, oddanost' a zbožnost: Humilitatem in illo, caritatem, pietatem divinitus condonatam, si quisquam incipiat, non poterit explicare. Pecunia apud eum numquam mansisse probatur, nisi forte tali hora offeretur, quando iam sol explicans cursum nocturnis tenebris ordinem daret et locum. Tantum reservabat, quantum diei sufficeret, non quantum cupiditas expetisset... - Ak by niekto začal rozprávat o jeho pokore, oddanosti a zbožnosti danej mu Bohom, nezvládol by to. Je dosvedčené, že peniaze si nikdy nenechával u seba, len ak by mu neboli poskytnuté $\mathrm{v}$ takej hodine, ked' už slnko vyplňovalo svoj beh a dávalo následníctvo nočným temnotám. Len tol'ko z nich si ponechával, kolko by postačovalo na deň, nie kol'ko by si vyžadovala žiadostivost' (Victor Vitensis 2.7; Victor von Vita 2011, 68).

V africkej cirkvi neprejavovali svoju lásku len biskupi voči svojim ovečkám, ale aj veriaci voči svojim biskupom. Všetok zástup katolíckych veriacich sa tešil, ked’ bol uvedený do svojho úradu biskup Eugenius: Ordinato itaque episcopo Eugenio, viro sancto deoque accepto, sublimis nata est laetitia et gaudium cumulatum est ecclesiae dei. Exultans multitudo catholica sub barbara dominatione de ordinatione pontificis reparati - ked’ teda bol ustanovený do úradu biskup Eugenius, muž svätý a Bohu milý, zrodila sa vel'ká veselost’ a bola dovŕšená radost̉ Božej cirkvi. Plesal katolícky lud pod barbarskou vládou nad novým nastolením pastiera (Victor Vitensis 2.6; Victor von Vita 2011, 66). Ked' zomrel kartáginský biskup Deogratias, ludia tak túžili po tomto biskupovi, že by neváhali roztrhat' jeho telo a kúsok si z neho zobrat: Cuius amore et desiderio populus attentus potuerat membra digni corporis rapere, nisi consilio prudenti, dum avocatur, nesciente multitudine sepeliretur - lud ovládnutý láskyplnou túžbou po ňom bol by ukradol údy dôstojného tela (ako relikvie), keby na základe rozumnej úvahy nebol pochovaný bez vedomia pospolitosti, ktorú odvolali inam (Victor Vitensis 1.27; Victor von Vita 2011, 48). Tu ale treba povedat', že ich motiváciou mohla byt túžba vlastnit̉ relikviu v ich očiach svätého muža.

Predsa však sem-tam nám Victor prezradí aj útržky informácií o fungovaní a štruktúre africkej cirkvi, ale nie je ich vela. Tak sa dozvedáme, že sídelný biskupský kostol v Kartágu sa nazýval ecclesia Restituta a že Geiserich z neho vyhnal katolíkov a pridelil ho ariánom: Pulso namque episcopo ... ilico eclessiam nomine Restitutam, in qua episcopi semper commanebat, suae religionis mancipavit - po vyhnaní onoho biskupa ... nárokoval si pre svoje náboženstvo kostol nazývaný Restituta, v ktorom vždy mali sídlo biskupi (Victor Vitensis 1.15; Victor von Vita 2011, 40). Tiež z diela získavame správu o senioráte $\mathrm{v}$ správe cirkevných provincií, kde hlavou biskupov bol ten, kto bol najdlhšie vo svojom úrade, bez ohladu na to, aké významné alebo nevýznamné bolo jeho sídlo. Z tohto pravidla bolo vyňaté samozrejme Kartágo, ktorého biskup mal vždy prednostné postavenie: Qua de re plurimos sacerdotum tunc novimus relegatos, sicut ... Crescentem metropolitanum Aquitanae civitatis, qui centum viginti praeerat episcopis - vieme, že z tejto príčiny bolo vtedy poslaných do vyhnanstva vel'ké množstvo biskupov, tak ako ... Crescentus metropolita mesta Aquitana, ktorý stál na čele stodvadsiatich biskupov(Victor Vitensis 1.23; Victor von Vita 2011, 46; Victor von Vita 2011, 162 pozn. 56).

Najväčšia pozornost’ v diele je samozrejme venovaná kartáginskému biskupovi Eugeniovi, ktorý je vykreslovaný $\mathrm{z}$ mnohých pohladov jeho správania, pričom sa prejavuje najmä jeho pokora. Victor o ňom hovorí ako o Božom človeku - hominis dei, o vernom služobníkovi a vyznavačovi iste servus et confessor fidelis a spomína passio veri pontifici - utrpenie pravého pastiera (Victor Vitensis 3.44; Victor von Vita 2011, 130). Počas internácie u Antonia, aspoň tak mi to vychádza $\mathrm{z}$ textu, dobrovolne kvôli krutým podmienkam ostatných biskupov a klerikov poslaných do vyhnanstva asperitate cilicii senilem adtereret corpus, ... super humum cubitans - staré telo si dral drsným odevom, ... spával na zemi, čo malo za následok, že ... aliquando sensit infestum paralysis morbum - ... raz zacítil život ohrozujúci záchvat mŕtvice (Victor Vitensis 3.43; Victor von Vita 2011, 130). Napokon sa však Boh k nemu prihlásil a zbavil ho jeho choroby (Victor Vitensis 3.44; Victor von Vita 2011, 130). 
Viacero dalších prípadov sme už spomenuli v predchádzajúcom výklade. Tu chcem ukázat', ako Boh Eugeniovým prostredníctvom urobil mocný čin uzdravenia a zároveň Victor Eugenia pripodobňuje Kristovi, ktorý tiež potretím očí vrátil slepcovi zrak (Mk 8.22-25; 10.46-52; Štúdijná Biblia 2015, 1670, 1677-1678). Boh v noci vo sne navštívil v Kartágu slepca a prikázal mu íst za biskupom Eugeniom, aby mu ten vrátil zrak: ostendit deus noster quoddam miraculum per servum suum fidelem Eugenium...; ... surge, vade ad servum meum Eugenium episcopum - ukázal náš Boh akýsi zázrak prostredníctvom svojho verného služobníka Eugenia...; ... vstaň a chod’k môjmu služobníkovi biskupovi Eugeniovi. Ked’k nemu slepec prišiel, vyrozprával mu svoj sen a Boží príkaz, Eugenius sa bránil slovami: Recede a me, frater; peccator sum et indignus et super omnes homines delinquens, utpote qui et in haec tempora servatus sum - odstúp odo mňa, brat, som hriešnik a nehodný a chybujúci viac ako všetci ludia a preto som bol zachovaný do týchto zlých časov. Slepec sa však nedal odbit' a nadalej naliehal. Eugenius nato: Iam tibi dixi, frater Felix, peccator ego homo sum - už som ti povedal, brat Felix, som hriešny človek. Napokon ale urobí, ako slepec žiadal a uprostred omše mu potrie oči vodou z prameňa, ktorým krstili nových členov cirkvi, a slepcovi sa otvoria oči: Simulque vexillo crucis consignans oculos eius, statim caecus visum domino reddente recepit - A akonáhle označil jeho oči znakom kríža, slepec pôsobením Pána hned' získal spät zrak (Victor Vitensis 2.47-50; Victor von Vita 2011, 92-94).

Pripodobnenie pozemskej púte Kristovej sa nachádza aj v dalších odstavcoch: Ariánski biskupi ho za tento zázračný skutok obvinili: hoc Eugenius per maleficia fecit - toto učinil Eugenius prostredníctvom zlých kúziel. Rovnaký postup použili protivníci proti Ježišovi, ked' ho obviňovali, že uzdravuje mocou zlého ducha ((Victor Vitensis 2.51; Victor von Vita 2011, 94; Lk 11.15; Štúdijná Biblia 2015, 1730). Ku Kristovi Victor prirovnáva Eugenia aj počas jeho mučenia, ked’ mu liali do hrdla ocot, ktorým ho chceli zahubit' a on ho odmietal pit: (Antonius) praecepit, ut acetum asperum nimisque acerrimum quaereretur; quod cum fuisset allatum, venerabilis senis recusantibus et nolentibus faucibus ingerabat - (Antonius) prikázal, aby vyhladali trpký a nadmieru ostrý ocot, ked' mu ho priniesli, lial ho ctihodnému starcovi do hrdla, hoci ten sa vzpieral a odmietal ho. Pripodobnenie je to síce násilné, ale vychádza zo samotného Victorovho textu hned’v nasledujúcej vete (Victor Vitensis 3.44; Victor von Vita 2011, 130; Mk 15.36; Štúdijná Biblia 2015, 1693 Mt 27.48; Štúdijná Biblia 2015, 1646; Lk 23.36; Štúdijná Biblia 2015, 1757; Jn 19.29; Štúdijná Biblia 2015, 1813).

$\mathrm{V}$ druhej časti štúdie pristúpim $\mathrm{k}$ porovnaniu postavenia biskupa $\mathrm{v}$ Afrike a vo zvyšku Rímskeho impéria. Pri vol'be biskupov nám bohužial' Victor neponúka vela informácií, čo je spôsobené najmä tou skutočnostou, že Geiserich a Hunerich zakázali nástup nových biskupov v prípade, ak starý biskup zomrel (Victor Vitensis 1.23; Victor von Vita 2011, 46). Situácia dospela do takého stavu, že v provincii Afrika zostalo zo 164 biskupov v r. 454 len 54, ktorí sa mohli zúčastnit vieroučnej debaty nariadenej Hunerichom v r. 484 (Victor Vitensis 1.29; Victor von Vita 2011, 48-50; Notitia provinciarum et civitatum Africae 55; Notitia provinciarum et civitatum Africae 1881, 119). ${ }^{14}$ Jedinou výnimkou bolo povolenie na ustanovenie kartáginských biskupov Deogratia v r. 454 a Eugenia v r. 480/481. Latinský text však hovorí o ordinovaní alebo ustanovení biskupa, čo je všeobecný termín pre celý postup ustanovenia biskupa a z toho sa nedá vyvodit, ako presne vyzerali jednotlivé kroky pri biskupovom uvedení do úradu. Pri ustanovení Deogratia Victor použil spojenia episcopo ordinari a episcopo constituto (Victor Vitensis 1.24; Victor von Vita $2011,46)$ a v prípade Eugenia ordinato episcopo (Victor Vitensis 2.6; Victor von Vita 2011, 66). K sociálnemu pôvodu biskupov sa neviem priamo vyjadrit', pretože Victor to nikde nespomína, dá

14 Victor udáva obdobie tridsiatich rokov (454 až 484) a dokonca hovorí len o troch doživších sa biskupoch. Tu je však dôveryhodnejší prameň Notitia provinciarum et civitatum Africae. 
sa vyvodit’ len z toho, že mnohí biskupi mali výborné vzdelanie, takže zrejme pochádzali z vyšších vrstiev rímskej spoločnosti (napr. Victor Vitensis 2.45 a 2.52; Victor von Vita 2011, 90 a 94).

Tiež je zložité vyjadrit’ sa k majetku a príjmom, ktorými disponovali jednotlivé cirkevné spoločenstvá vo Vandalskom královstve. Victor vo svojej prvej knihe píše o tom, ako Vandali plienili a vykrádali kostoly a mučili klerikov, aby im vydali zlato, striebro a dalšie poklady, ktoré cirkev uschovávala a o tom, ako Vandali vyháňali biskupov doslova nahých z ich sídiel, a to bud' do vyhnanstva alebo do otroctva, ak vyhnanstvo odmietli (Victor Vitensis 1.5; 1.14; Victor von Vita 2011,36; 40). Geiserich zabral výstavný kostol uprostred Kartága pre ariánske bohoslužby a Victor píše, že zabavil všetky kostoly vnútri mestských múrov aj s ich pokladmi a majetkami (Victor Vitensis 1.15; Victor von Vita 2011, 40). Nie vždy môžeme brat' Victorovo tvrdenie za bernú mincu, pretože o pár kapitol neskôr píše, že kartáginský biskup Deogratias predal všetky zlaté a strieborné nádoby, aby mohol vykúpit zajatcov, ktorých Vandali priviedli do Kartága po vyplienení Ríma v r. 455 (Victor Vitensis 1.25; Victor von Vita 2011, 46-48). Po vieroučnej dišpute v r. 484 odňal král Hunerich v Afrike proconsularis všetky kostoly a všetok majetok katolíkom a odovzdal ho ariánom (Victor Vitensis 3.2; Victor von Vita 2011, 100).

Vykupovanie zajatcov patrilo k povinnostiam biskupa, podobne ako starostlivost’ o núdznych. Tiež biskupi na území Vandalov sa starali o chudákov, pričom Victor spomína, že katolícki veriaci prinášali Eugeniovi svoje almužny, ktoré on okamžite vydal na charitu a pre seba si nechával len to najnutnejšie na živobytie (Victor Vitensis 2.7; Victor von Vita 2011, 66-68). O rozvoji cirkvi alebo budovaní kostolov a charitatívnych stavieb nemôže byt’ v tejto dobe $\mathrm{v}$ Afrike ani reči, Deogratias preto umiestňoval vykúpených zajatcov priamo v dvoch chrámoch, ktoré na tento účel vyčlenil (Victor Vitensis 1.25; Victor von Vita 2011, 46-48). Africkí biskupi prišli o privilegium fori, ktoré klerikom svojím ediktom z r. 355 pridelil rímsky cisár Constantius II. (Koštancius II. 337-361), ktoré ich vydelilo z právomoci svetských súdov a biskupov mohli súdit len na biskupských súdoch (Cod. Theod. 16.2.12; Codex Theodosianus 1962, I.2, 838 ). Právo súdit biskupov vo Vandalskej ríši si osoboval panovník a ukladal im tvrdé tresty vyhnanstva, palicovania alebo smrti (Victor Vitensis 2.45; 2.52; Victor von Vita 2011, 90-92; 94-96). Takisto biskupi nemohli zasahovat do mestských záležitostí, kedže tie prináležali vandalskej vrchnosti a okrem toho sa Victor k tomu nevyjadruje. Zostala ešte jedna činnost' prináležiaca do biskupskej starostlivosti, a to teologické dišputy. Svoje teologické vzdelanie využili africkí biskupi v r. 484 pri vel'kej diskusii medzi katolíckym a ariánskym duchovenstvom o pravost’ vierovyznania. Ariáni zastávali tézu, že Ježiš Kristus ako Boží syn nemá rovnakú podstatu ako Boh otec, kým katolíci stáli pevne na vierovyznaní, že Syn je rovnakej podstaty - homousios ako Otec, ktorá bola prijatá ešte na Nicejskom ekumenickom koncile v r. 325 (Zozulak 2016, 129-134; Suchánek - Drška 2013, 160-168; Lohse 2003, 39-50). Hoci sa africkí katolícki biskupi bránili, že nemôžu v tejto debate zastupovat katolícku cirkev aj z iných oblastí Rímskeho impéria, napokon sa debaty zúčastnili. Zrejme biskup Eugenius vypracoval traktát Liber fidei catholicae, v ktorom rozpracoval najdôležitejšie argumenty pre obranu zástancov poňatia, že Otec a Syn sú rovnakej podstaty. Tento traktát sa zachoval ako súčast diela Victora z Vity v jeho druhej knihe (Victor Vitensis 2.56-101; Victori episcopi Vitensis $1881,46-71)^{15}$ a ukazuje slušnú teologickú úroveň jeho autora/autorov (Steinacher 2016, 252-3). Napriek dobrej teoretickej základni a príprave na diskusiu to nakoniec nemalo význam, pretože ariánski biskupi obvinili katolíkov z narúšania priebehu diskusie, čo král Hunerich využil ako zámienku, aby poslal zhromaždených biskupov do vyhnanstva do polopúšte na juhu krajiny, aby tam obrábali pôdu, alebo na Korziku, aby tam stínali stromy na stavbu vandalských lodí (Victor Vitensis 3.17-19; Victor von Vita 2011, 110-112).

\footnotetext{
15 Niekedy je tento spis vnímaný ako tretia kniha diela Victora z Vity, ktoré sa potom delí na štyri knihy.
} 


\section{Záver}

Victor z Vity sa podujal napísat život a utrpenie katolíckej cirkvi v Afrike za vlády prvých dvoch vandalských panovníkov. Kedže je katolík a klerik, je jeho pohlad samozrejme skreslený jeho videním sveta. Barbari - ariáni sú tí zlí a prenasledujúci a katolíci tí dobrí a trpiaci. Napriek tomu si myslím, že jeho dielo dovoluje vyexcerpovat vela podrobností o osudoch katolíckej cirkvi a o osudoch jej hlavných predstavených - biskupov. Ak zhrnieme hlavný text tejto štúdie, vidíme, že sa africkí biskupi aj vo velmi tažkých časoch snažili vykonávat svoj úrad podobným spôsobom, ako pred príchodom Vandalov a podobným spôsobom, ako ich súputníci - biskupi v iných častiach Rímskej ríše. Vandali im však v mnohých činnostiach bránili alebo im k vykonávaniu týchto činností zobrali prostriedky a možnosti. Hlavnou náplňou ich činnosti bola starostlivost’ o im zverených členov spoločenstva a to nielen $\mathrm{v}$ duchovnom, ale aj v materiálnom zmysle. Do popredia vystupuje ich charitatívna činnost', skromnost’ a pokora a ich neochvejná viera, ktorú nedokázal zlomit ani tlak vládnucich panovníkov - ariánov a ich pomocníkov z radov ariánskeho duchovenstva, tlak, ktorý často končil bitím, vyhnanstvom alebo smrtou. Mnohí biskupi sú spomínaní aj s ich menami a s konkrétnymi skutkami. Najviac priestoru dostáva kartáginský biskup Eugenius, s ktorým Victora spájal pevný vztah, a ktorý je pre neho prototypom pravého a verného katolíckeho biskupa, ktorý sa svojím cnostným životom plným lásky a milosrdenstva voči blížnym a podstupovaním utrpenia snaží pripodobnit svojmu Pánovi - Ježišovi Kristovi.

\section{REFERENCES}

\section{Primary sources}

Concilium Nicaenum I, Canones (Altera Lectio).

http://www.documentacatholicaomnia.eu/03d/0325-0325,_Concilium_Nicaenum_I,_Canones_ (Altera_Lectio),_GR.pdf (grécky text);

http://www.documentacatholicaomnia.eu/04z/z_0325-0325_Concilium_Nicaenum_I__ Documenta_LT.doc.html (latinský text).

Cyprianus, Thascius Caecilius. 1871. Epistulae. In Thascii Caecilii Cypriani Opera omnia. Recensuit et commentario critico instruxit Guilelmus Hartel (CSEL 3/2). Vindobona, 463-842.

Codex Theodosianus. 1962. Theodosiani libri XVI cum constitutionibus Sirmondianis et leges novellae ad Theodosianum pertinentes. Edidit Th. Mommsen, F. M. Meyer. Berlin.

Der erste Clemesbrief. 1899. Untersucht und herausgegeben von Rudolf Knopf. Leipzig.

Notitia provinciarum et civitatum Africae. 1881. In Petschenig (ed.). Corpus Scriptorum Ecclesiasticorum Latinorum (CSEL) VII Vindobonae, 115-134.

Dokumenty prvých dvoch ekumenických snemov. 1999. Z gréčtiny preložil, úvody a vysvetlivky napísal Marcel Gajdoš. Prešov.

Paulinus. 1961. Vita sancti Ambrosii. In M. Pellegrino (ed.) Paulino di Milano: Vita di S. Ambrogio. Roma.

Prokopios von Kaisareia. 1966-1971. Bella / Historien 1-8, ed. und dt. Übers. Otto Veh, Prokop Werke 2 - 4: 2. Gotenkriege, 3. Perserkriege, 4. Vandalenkrieg, griechisch und deutsch, Samlung Tusculum. München.

Sancti Irenaei, episcopi Lugdunensis et martyri. 1857. Detectionis et eversionis falso cognominatae agnitionis seu contra haereses libri quinque (PG 7). Thurnholt.

Sulpicius Severus. 1967. Vita sancti Martini. In Sulpice Sévère, Vie de Saint Martin t. 1 (Sources Chrétienes t. 133). Paris. 
Štúdijná Biblia. 2015. Slovenský ekumenický preklad. Bratislava.

Tertulliani liber de praescriptione haereticorum.

http://thelatinlibrary.com/tertullian/tertullian.praescrip.shtml.

Traditio apostolica. 1991. Apostolische Überlieferung. Lateinisch und deutsch. Bersetzt von Wilhelm Geerlings (Fontes Christiani Bd. 1). Freiburg im Breisgau.

Victor of Vita. 1992. History of the Vandal Persecution. Translated with Introduction and Notes by John Moorhaed. Liverpool.

Victor Vitensis. 1879. Historia persecutionis Africanae provinciae sub Geiserico et Hunirico regibus Wandalorum, ed. Karl Halm, Monumenta Germaniae historica (MGH) Auctores antiquissimi 3, 1. Berlin, 1-59.

Victori episcopi Vitensis. 1881. Historia persecutionis Africanae provinciae. In Petschenig (ed.). Corpus Scriptorum Ecclesiasticorum Latinorum (CSEL) VII Vindobonae, 1-107.

Victor von Vita, 2011. Historia persecutionis Africanae provinciae temporum geiserici et Hunerici regum Wandalorum. Kirchenkampf und Verfolgung unter der Vandalen in Africa. Lateinisch und deutsch. Herausgeben, eingeleitet und übergetzt von Konrad Vössing. Texte der Forschung 96. Darmstadt.

\section{Secondary sources}

Babic, Marek. 2009. Od antiky k stredoveku. Dejiny neskorého rímskeho cisárstva medzi rokmi 284 - 476. Brno.

Bednaříková, Jarmila. 2003. Stěhování národů. Praha.

Cameron, Averil. 1985. Procopius and the Sixth Century. Berkeley.

Howe, Tankred. 2007. Vandalen, Barbaren und Arianer bei Victor von Vita. Frankfurt am Mein.

Suchánek, Drahomír - Drška, Václav. 2013. Církevní dějiny. Antika a středověk. Praha.

Jirkal, Emanuel. 2020. Postavenie biskupa na prelome antiky a stredoveku. In Glejtek, Miroslav a kol. Arcibiskupi a biskupi Uhorska. Moc prelátov a jej prejavy v stredoveku. Bratislava. (V tlači.)

Katechizmus katolíckej cirkvi. 1998. Trnava.

Krause, Jens-Uwe. 2018. Geschichte der Spätantike. Tübingen.

Lohse, Bernhard. 2003. Epochy dějin dogmatu. Jihlava.

Markschies, Christoph. 2005 Mezi dvěma světy. Dějiny antického křestanství. Praha.

Merrils, Andrew. H. (ed.). 2004. Vandals, Romans and Berbers: New Perspectives on Late Antique North Africa. London.

Moorhead, John. 1992. Introduction. In VICTOR OF VITA: History of the Vandal Persecution. Translated with Introduction and Notes by John Moorhaed, ix-xx.

Neumann, Johannes. 1980. Bischof I. In Theologische Realenzyklopädie, Band VI, Bibel - Böhmen und Mähren. Berlin - New York, 653-682.

Pietri, Charles. 1995. Die Geschichte des Christentums. Religion, Politik, Kultur. Band 2: Das Entstehen der einen Christenheit $(250$ - 430). Freibur - Basel - Wien.

Pietri, Luce. 2001. Die Geschichte des Christentums. Religion, Politik, Kultur. Band 3: Der Lateinische Westen und der byzantinische Osten (431 - 642). Freiburg - Basel - Wien.

Steinacher, Roland. 2016. Die Vandalen. Aufstieg und Fall eines Barbarenreichs. Stuttgart.

Steinacker, Peter. 1989. Katholizität. In Theologische Realenzyklopädie, Band XVIII, Katechumenat/ Katechumenen - Kirchenrecht. Berlin - New York, 72-80. 
Vössing, Konrad. 2011. Einleitung. In Victor von Vita, Historia persecutionis Africanae provinciae temporum geiserici et Hunerici regum Wandalorum. Kirchenkampf und Verfolgung unter der Vandalen in Africa. Darmstadt, 11-29.

Vössing, Konrad. 2014. Das Königreich der Vandalen. Geiserichs Herrschaft und Imperium Romanum. Darmstadt.

Zozulak, Ján. 2016. Byzantská filozofia. Plzeň.

\begin{abstract}
SUMMARY: THE PORTRAYAL OF THE BISHOP'S POSITION IN THE WORK HISTORIA PERSECUTIONIS AFRICANAE PROVINCIAE TEMPORUM GEISERICI ET HUNERICI REGUM VANDALORUM BY VICTOR OF VITA. This topic significantly reflects a hostile attitude of the ruling Arian Vandals to the Catholic Church which often proceeded with the open persecution and the effort of Vandals to often violently convert the majority of Roman population belonging to the Catholic Church to the Arian faith. It implies the content and diction of the Victor of Vita's work which up to certain extent becomes a hagiographic writing. Through the portrayal and representation of the bishop, the contribution follows more levels, courteous addressing of bishops from the side of Victor of Vita, many bishops had excellent level of knowledge, they were ready to undergo sufferings and even death because of their faith. A large part of their activity during these difficult times was a charity, the preparedness to serve to needy and poor people and Victor emphasizes their humility and modesty. In comparison with the other parts of the Roman Empire, the bishops had very limited possibilities, vandals often confiscated church property, in spite of this fact a charity created the essential part of their activity including also buying prisoners and the support of poor people. The pastoral activity of bishops was under great pressure, bishops had very limited possibilities to intervene in favour of the members of their community against the Civil Service. Bishops manifested their excellent theological knowledge and preparedness to lead theological debates with their Arian opponents. Bishops in Africa tried to live ever more according to the example of their Lord Jesus Christ.
\end{abstract}

PhDr. Emanuel Jirkal, PhD.

Constantine the Philosopher University in Nitra

Faculty of Arts

Department of History

Hodžova 1

94974 Nitra

Slovakia

ejirkal@ukf.sk 